\title{
Питання психології
}

УДК 378.018.8:159.9-051

DOI: 10.33099/2617-6858-21-64-6-105-109

Столярова О. М. здобувачка $P h D$,

Уманський державний педагогічний

університет імені Павла Тичини

https://orcid.org/0000-0003-4320-7370

Сафін О. Д. доктор психологічних наук, професор, завідувач кафедри психології, Уманський держсавний педагогічний університет імені Павла Тичини https://orcid.org/0000-0001-5745-8635

Діхтяренко С. Ю. кандидат психологічних наук, доцент, доцент кафедри психології, Уманський державний педагогічний університет імені Павла Тичини https://orcid.org/0000-0003-4506-1221

Рабодзей T. С. здобувачка PhD, Уманський державний педагогічний університет імені Павла Тичини https://orcid.org/0000-0001-7175-3286

\section{МОТИВАЦЙНА ГОТОВНІСТЬ ЗДОБУВАЧІВ ВИЩОЇ ОСВІТИ ДО МАЙБУТНЬОЇ ПРОФЕСІї ПСИХОЛОГА}

У статті розглянуто проблему визначення та обгрунтування змісту мотиваційної готовності до професійної діяльності майбутніх психологів. Зазначається, щзо мотивачійна готовність є необхідною умовою успішної професійної самореалізаиії молодого фахівия - психолога. Для підвищення рівня підготовки сучасних фахівиів до успішної трудової діяльності та конкурентоспроможності на ринку пращі ключовим завданням є розвиток професійної мотиваиії та особистісна заиікавленість в обраній спеиіальності. Здійснено теоретичний аналіз поглядів науковиів з цісї проблематики. Визначено, щяо мотиваиійна готовність є однією із умов успішного виконання психологами майбутньої професійної діяльності.

Ключові слова: мотивачійна готовність; професійна діяльність; професійна самореалізація; професійна мотиваиія; майбутній психолог.

Вступ. В умовах складної військовополітичної і соціально-економічної ситуації в Україні підвищуються вимоги до рівня професійної підготовки майбутніх психологів як фахівців, які зможуть надавати кваліфіковану допомогу тим, хто ії потребує. До дипломованих психологів ставляться такі вимоги, як: володіння високим рівнем загальної культури, вміння успішно вирішувати соціальні завдання, прагнення до професійного зростання, професійна мобільність. Здійснення підготовки спеціалістів такого рівня неможливе без сформованої у них мотиваційної готовності до професійної діяльності ще під час здобування освіти у закладах вищої освіти.

Молоді люди не завжди можуть здійснити адекватну, професійну самоідентифікацію,

щоб зрозуміти, чи відповідають їхні власні якості та задатки вимогам обраної спеціальності. Знання чинників, що детермінують особливості професійного визначення майбутніх психологів, дозволяе спрогнозувати процес їхнього професійного розвитку. Саме тому формування мотиваційної готовності здобувачів вищої освіти до майбутньої професії психолога $є$ надзвичайно актуальною проблемою.

Мета дослідження. Мета статті полягає у розкритті наукових підходів щодо проблеми мотиваційної готовності до професійної діяльності майбутніх психологів.

Теоретичне підгрунтя. Дослідженню проблеми формування мотивації присвячено багато праць (І.П. Андрійчук, С.С. Занюк, С.П. Ільїн, О.М. Леонтьєв, С.Г. Москвичов, В.А. 


\section{Питання психології}

Семиченко, Х.Хекхаузен, Д.Аткінсон, Д.Халл, А.Маслоу та ін. Мотивація розуміється як джерело активності і водночас як система збудників будь-якої діяльності людини. Уперше слово мотивація було використане А.Шопенгагауером у статті «Чотири принципи достатньої причини» [3, С. 65].

Мотивація, як психологічне явище трактується на сучасному етапі розвитку науки по-різному [1]. В одному випадку - як сукупність чинників, що підтримують i спрямовують, тобто визначають поведінку (Ж.Годфруа, К.Мадсен), в іншому - як сукупність мотивів (К.К. Платонов), у третьому - як спонукання, що викликає активність організму й визначає спрямованість особистості (П.М. Якобсон). Будь-яку форму поведінки можна пояснити як внутрішніми, так і зовнішніми причинами [2]. Внутрішніми чинниками, що впливають на поведінку особистості, $є$ психологічні властивості суб'єкта: мотиви, потреби, цілі, наміри, бажання, інтереси. Під зовнішніми чинниками впливу розуміють умови та обставини діяльності особистості, стимули, що походять безпосередньо із ситуації. Мотивація постає як процес безперервного вибору та прийняття рішень на основі аналізу поведінкових виборів [4]. На думку О.М. Леонтьєва і Б.М. Теплова на розвиток особистості у професійній діяльності здійснює значний вплив іiі мотиваційна сфера. В.Я. Акуніна та Н.В. Нестерова вважають, що становлення майбутнього фахівця можливе лише при сформованому мотиваційно-ціннісному відношенні.

Методи дослідження. Теоретичний аналіз, синтез, узагальнення.

Результати і обговорення. Мотиваційну сферу людини з погляду її розвиненості можна оцінювати за такими параметрами: широта, гнучкість та ієрархічність. Під широтою мотиваційної сфери розуміється якісне багатство мотиваційних чинників, представлених на кожному рівні. Чим більше у суб'єкта мотивів, потреб та цілей, тим більш розвиненою $\epsilon$ його мотиваційна сфера. Мотивація пояснює цілеспрямованість дій, організованість та стійкість цілісної діяльності, спрямованої на досягнення певної мети.
Насамперед проблема формування мотиваційної готовності здобувача вищої освіти до майбутньої професії зароджується на етапі профорієнтаційної роботи. А саме зацікавленість у виборі майбутньої спеціальності психолога. Вибір майбутньої професії, як і будь-який вибір - це прийняття рішень при великій кількості альтернативних варіантів та необхідності враховувати різноманітні чинники. $\mathrm{y}$ дослідженнях сучасних науковців розглядається формування інтересу до вибору професії через комплекс компонентів. У дослідженнях М.Левітова ці компоненти поєднано у три групи: мотиваційні компоненти, в яких відбивається оцінка професії, іiі суспільна значущість; компоненти підготовки до трудової діяльності - знання, вміння та навички; індивідуально-психологічні особливості мислення. Мотиваційний компонент визначається моральними якостями та функціональними властивостями особистості. До професійного компоненту належать знання про конкретну професію. До психологічного компоненту включено психічні та характерологічні показники особистості, які $\epsilon$ передумовами успішного оволодіння обраним видом трудової діяльності.

Під час проведення профорієнтаційної роботи майбутні здобувачі вищої освіти мають змогу ознайомитись із значущістю професії психолога, з'ясувати напрями діяльності, визначити його місце на сучасному ринку праці та розширити власне, індивідуальне бачення майбутньої професії, тобто професійно самовизначитись. Під час процесу професійного самовизначення для майбутніх здобувачів вищої освіти за напрямом «Психологія» доцільно використовувати такі форми роботи як: професійна просвіта, професійна діагностика, розвиток інтересів, здібностей, схильностей, професійна консультація. Виходимо з того, що професійне самовизначення $\epsilon$ не лише актом вибору, а й має динамічний, професійний характер, здійснюється і на подальших етапах життя людини.

Важливе завдання вищої школи формування професійних мотивів навчання здобувачів вищої освіти, вироблення у них потреби в опануванні професійних знань, вмінь i навичок [5]. Водночас потрібно 


\section{Питання психології}

враховувати, що студентський період життя , а саме час здобування майбутньої професії припадає переважно на період пізньої юності або ранньої дорослості, який характеризується оволодінням усім різноманіттям соціальних ролей дорослої людини, отриманням права вибору, набуттям певної юридичної та економічної відповідальності. включенням молодої людини в усі види соціальної активності. Навчання у закладі вищої освіти $€$ найважливішим етапом освоєння майбутньої професії, піi професійним становленням. Зважаючи на ці вікові та соціальні аспекти можна стверджувати, що процес формування мотивації до майбутньої професії психолога потребує корекції та управління 3 боку викладачів, що здійснюють освітній процес.

При наявності професійної мотивації пізнавальна діяльність здобувача має особистісний та наполегливий характер. Мотивація досягнення успіху визначає любов і захоплення процесом навчання. Майбутні психологи виявляють ініціативу, створюють навколо себе творчу пізнавальну атмосферу. Демонструють готовність до успішної, результативної навчально-професійної діяльності. Мотиваційна готовність до майбутньої професії психолога зароджується та розвивається в процесі навчання та має свої витоки у мотиваційній готовності оволодіти обраною професією. Формування мотивації складається з оцінки здобувачів вищої освіти різних аспектів навчального процесу, його змісту, форм, способів організації враховуючи їхні особисті та індивідуальні потреби і цілі, які можуть співпадати або не співпадати 3 цілями навчального процесу. Процес навчання для здобувачів вищої освіти здійснюється не у т. 3. особистому просторі, а у складному взаємооб'єднанні соціальних процесів. Для формування позитивної мотивації навчальнопрофесійної діяльності здобувач вищої освіти повинен стати іiі суб'єктом: виявляти вільну пізнавальну активність, інтелектуальну ініціативу і самостійність у прийнятті рішень щодо вибору шляхів і змісту самоосвіти; збагачувати власний внутрішній світ, бути відкритим до нового досвіду; орієнтуватися на своє майбутне, будувати особисту перспективу; розвивати самокритичність та самооцінку; виховувати у собі потребу втілювати у життя особисті плани, реалізовувати потенційні можливості [1].

Мотивація посилюється, якщо виникає зв'язок між засвоєнням знань, збагачення власного досвіду 3 вимогами й функціями майбутньої професії. Лише за наявності у здобувача вищої освіти потреби у самореалізації розвиваються його загальні й професійні здібності. Зазначимо, що основою будь-якої професійної освіти $\epsilon$ перехід від навчальної діяльності, що актуально здійснюється, до засвоєння майбутніми фахівцями (у нашому випадку - психологами) професійної діяльності, трансформація пізнавальних мотивів здобувача вищої освіти у професійні мотиви фахівця.

До основних професійних мотивів психологів належать мотиви призначення професії, діяльнісно-результативні мотиви, мотиви соціального престижу професії психолога, мотиви міжособистісного спілкування, мотиви реалізації своїх вмінь у професії. Професійна мотивація є основним чинником, що впливає на ефективне виконання трудової діяльності. Професіоналізм майбутнього психолога передбачає об'єктивність при сприйнятті та аналізі складних життєвих ситуацій; вміння визначити коло доступних йому для виконання завдань; готовність застосувати власний досвід у відповідності із новими обставинами життя. Можна стверджувати, що готовність майбутнього психолога до професійної діяльності не зводиться лише до оволодівання спеціальними знаннями, а базується на мотиваційній сфері особистості. Адекватно сформована мотиваційна готовність до майбутньої професії визначає велику вірогідність успіху та конкурентоспроможності у професійній діяльності. Таким чином, особливості функціонування і розвиток мотиваційної сфери майбутнього психолога забезпечують його професійне становлення та успіх у професійній діяльності.

Висновки. Отже мотиваційна готовність $\epsilon$ необхідною умовою успішної професійної самореалізації молодого фахівця-психолога. Для підвищення рівня підготовки сучасних фахівців до успішної трудової діяльності та конкурентоспроможності на ринку праці 


\title{
Питання психології
}

ключовим завданням є розвиток професійної мотивації та особистісна зацікавленість в обраній спеціальності. Вища школа має системно формувати мотивацію здобувачів вищої освіти до професійної діяльності за допомогою фахової практики та розкриття можливостей використання професійного досвіду 3 позитивним підкріпленням останнього. Саме такий підхід забезпечить можливість не лише опанування базових аспектів професії, а й сприятиме виробленню професійних установок, оперативно-рольових дій у реалізації професійних функцій.

\section{Список використаних джерел}

1. Болтівець С.І. Українська психологічна термінологія: словник-довідник / укл. С.І. Болтівць, Н.В. Слободяник, М.-Л.А. Чепа, Н.В. Чепелєва. К.: ДП «Інформаційно-аналітичне агентство», 2010. 302 с.

2. Занюк С. Психология мотивации. К.: Ника-Центр: Эльга-Н, 2001. 352 с.

3. Ильин Е.П. Мотивация и мотивы. СПб.: Питер, 2011. 512 с.

4. Москвичев С.Г. Проблемы мотивации в психологических исследованиях. К.: Наукова думка, 1975. $144 \mathrm{c}$.

5. Семиченко В.А. Проблемы мотивации поведения и деятельности человека. Модульный курс психологии. Модуль «Направленность» (Лекции, практические занятия, задания для самостоятельной работы): учебное пособие. К.: Миллениум, 2004. 521 с.

\section{References}

1. Boltivec' C.I. Ukrai'nc'ka pcyxologichna terminologija: clovnyk-dovidnyk [Ukrainian Psychological Terminology: Glossary] / ukl. C.I. Boltivc', N.V. Clobodjanyk, M.-L.A. Chepa, N.V. Chepeljeva. K.: DP «Informacijno-analitychne agentctvo», 2010.302 s. (in Ukranianl

2. Zanjuk S. Psihologija motivacii [Psychology of motivation]. K.: Nika-Centr: Jel'ga-N, 2001. 352 s. (in Russian)

3. Il'in E.P. Motivacija i motivy [Motivation and motives]. SPb.: Piter, 2011.512 s. (in Russian)

4. Moskvichev S.G. Problemy motivacii v psihologicheskih issledovanijah [Motivation Problems in Psychological Research]. K.: Naukova dumka, 1975. 144 s. (in Russian)

5. Semichenko V.A. Problemy motivacii povedenija i dejatel'nosti cheloveka. Modul'nyj kurs psihologii. Modul' «Napravlennost'» (Lekcii, prakticheskie zanjatija, zadanija dlja samostojatel'noj raboty) [Problems of motivation of human behavior and activity. Modular course in psychology. Module "Orientation" (Lectures, practical exercises, assignments for independent work)]: uchebnoe posobie. K.: Millenium, 2004. 521 s. (in Russian)

\author{
Резюме \\ Столярова О. М. соискательница PhD кафедри \\ психологии, Уманский государственный \\ педагогический университет имени Павла Тычины \\ Сафин О. Д. доктор психологических наук, \\ профессор, заведующиий кафедрой психологи, \\ Уманский государственный педагогический \\ университет имени Павла Тычиньь
}

Дихтяренко С. Ю. кандидат психологических наук, дочент, дочент кафедры психологии, Уманский государственный педагогический университет имени Павла Тычины

Рабодзей T. С. соискательница РhD кафедри психологии, Уманский государственный педагогический университет имени Павла Тычины

МОТИВАЦИОННАЯ ГОТОВНОСТЬ СОИСКАТЕЛЯ ВЫСШЕГО ОБРАЗОВАНИЯ К БУДУЩЕЙ ПРОФЕССИИ ПСИХОЛОГА

В статье рассмотрена проблема определения и обоснования содержания мотиваиионной готовности к профессиональной деятельности будущих психологов. Отмечается, что мотивачионная готовность является необходимым условием успешной профессиональной самореализации молодого специалиста - психолога. Для повышения уровня подготовки современных спеииалистов к успешной 


\section{Питання психології}

трудовой деятельности и конкурентоспособности на рынке труда ключевой задачей является развитие профессиональной мотивации и личностный интерес в выбранной специальности. Проведен теоретический анализ взглядов ученых по этой проблематике. Определено, что мотивационная готовность является одним из условий успешного выполнения психологами будущей профессиональной деятельности.

Ключевые слова: мотивационная готовность; профессиональная деятельность; профессиональная самореализация; профессиональная мотиващия; будущий психолог.

\section{Summary}

Stoliarova O. Postgraduate Student, Pavlo Tychyna

Uman State Pedagogical University

Safin O. Doctor of Psychological Sciences, Professor, Chair of the Department of Psychology, Pavlo Tychyna Uman State Pedagogical University

Dihtyarenko S. Candidate) of Psychological Sciences, Docent, Associate Professor of the Department of Psychology, Pavlo Tychyna Uman State Pedagogical University

Rabodzey T. Postgraduate Student, Pavlo Tychyna Uman State Pedagogical University

\section{MOTIVATIONAL READNESS OF THE STUDENTS FOR THE FUTURE PROFESSION OF A} PSYCHOLOGIST

Introduction. Today the requirements for the level of professional training of future psychologists as specialists who will be able to provide qualified assistance to those who need it are increasing. Certified psychologists are required to have a high level of general culture, the ability to successfully solve social problems, the desire for professional growth, professional mobility. Training of specialists of this level is impossible without the motivational readiness for professional activity formed in them during their education in higher education institutions.

Purpose. The purpose of the article is to reveal scientific approaches to the problem of motivational readiness for professional activities of future psychologists.

Methods. Theoretical analysis, synthesis, comparison.

Originality. A professional motivation is the main factor influencing the effective performance of work. The professionalism of the future psychologist implies objectivity in the perception and analysis of complex life situations; the ability to determine the range of tasks available to him to perform; willingness to apply their own experience in accordance with the new circumstances of life. It can be argued that the readiness of the future psychologist for professional activity is not limited to the acquisition of special knowledge, but is based on the motivational sphere of personality. Adequately formed motivational readiness for the future profession determines the high probability of success and competitiveness in professional activities. Thus, the peculiarities of the functioning and development of the motivational sphere of the future psychologist ensure his professional development and success in professional activities.

Conclusion. The motivational readiness is a necessary condition for successful professional self-realization of a young psychologist. To increase the level of training of modern specialists for successful work and competitiveness in the labor market, the key task is to develop professional motivation and personal interest in the chosen specialty. Higher education should systematically motivate higher education students to professional activities through professional practice and the opening of opportunities for the use of professional experience with the positive reinforcement of the latter. This approach will provide an opportunity not only to master the basic aspects of the profession, but also contribute to the development of professional attitudes, operational and role actions in the implementation of professional functions.

Key words: motivational readiness; professional activity of a psychologist; motivational and professional orientations; future psychologist.

Автори заявляють про відсутність конфлікту інтересів.

Recelved/Поступила: 18.12.21. 